\title{
A Literature Review to Explore E-Learning in Universities
}

\author{
TERESA ANNA Rita GENTILE \\ tgentile@unicz.it \\ University of Catanzaro
}

\author{
ERNESTO DE NITO \\ ernesto.denito@unisa.it
}

University of Salerno

\author{
ROCCO REINA \\ rreina@unicz.it \\ University of Catanzaro
}

\author{
ANNA MARIA MELINA \\ amelina@unicz.it \\ University of Catanzaro
}

\begin{abstract}
The article aims to provide a literature review on e-learning and e-learning design in the university context. The aim, more precisely, is to investigate the type of attention that researchers give to e-learning and e-learning design and what are the next trends in e-learning in the university context. The literature review focused on the analysis of two international journals: Internet and Higher Education (IEHE) and Computer \& Education (CEE). These journals have been selected from an international ranking on the SCImago Journal \& Country Rank (SJR) portal. The investigation takes place at two specific times: (1) a first selection based on keywords on the journal sites; (2) a second selection phase to choose the most consistent studies through abstract analysis. This research makes it possible to contribute, through a review of the literature, to make a mapping of the evolution of e-learning design and elearning studies within universities at international level, taking as a survey reference a fairly long period of time in the analysis of the articles (from 1997 to 2018).
\end{abstract}

\section{Introduction}

The term 'Information and Communication Technologies' (ICT or ICTs) refers to the use of devices and infrastructures that facilitate the transfer of information through digital tools (Lloyd, 2005; Zuppo, 2012). Within the study on the learning process in universities, the rapid 
spread of the use of the Internet and the various forms of ICT allowed the improvement of teaching and learning methodologies (Huang, Lin and Huang, 2012), the redefinition of some strategies in the context of teaching and learning concepts (Klimov, 2012) as well as the evolution from traditional forms of learning in e-learning (Alkhalaf, 2012).

When it comes to adopting e-learning in universities, two questions arise. First, e-learning is a teaching and learning system provided on a digital device such as a computer or mobile device (Brown and Voltz, 2005; Clark and Mayer, 2011) to enable the transfer of learning materials through the use of specially designed online tools; which can cover part or all of the course where technology mediates the learning process and which aims to increase an integrated training environment (CNPA, 2007; Carroll, 2013; Gros and García-Peñalvo, 2016; Loh et al., 2016). Secondly, e-learning systems, according to Fee (2009), consist of three components: (a) technology, (b) learning content, and (c) e-learning design. Following Fee's (2009) model, in the literature on e-learning in universities, it emerges that it is particularly rich in aspects related to technology (Bhuasiri et al., 2012; Songkram, 2015; Masud, 2016) and learning content (Adeola, Adewale and Alese, 2013; Almpanis, 2015; Oproiu, 2015), while on the contrary the problem of e-learning design has not been studied in depth (Islam, Beer and Slack, 2015; Urh, 2015).

Therefore, this article aims to examine the different approaches to the study conducted in the literature on e-learning issues in education. The aim, more precisely, is to investigate the type of attention paid to e-learning and, in particular, to e-learning design by researchers and professionals and what are the next trends in e-learning in the university context.

\section{Literature review}

'Good learning' in e-learning systems depends on a combination of work technology, meaningful content and effective e-learning design (Fee, 2009). These three components are complementary and must be carefully combined: the design must make maximum use of the content and the technology must allow both content and design. For professionals involved in e-learning development, not only access to content and technology is important, but also design.

Specifically, therefore, the technology is intended as a basic infrastructure capable of enabling the implementation of e-learning (Urh et al., 2015) through the transfer of information during the training course or the acquisition of skills by users (Ghiringhelli and Quacquarelli, in Nacamulli, 2003). The learning content, on the contrary, refers to the educational material and associated activities (Al-Yahya et al., 2015). Finally, learning/e-learning design (design of elearning) is the set of educational decisions (Horton, 2011) on how to plan learning activities and interventions (Conole, 2013: 7), on how to set objectives and educational plans through appropriate use of resources and technologies (Rienties, Toetenel and Bryan, 2015). According to Trentin (2001), the design of learning is characterised by a complex educational process comprising four phases: (1) identification of the general objectives of the training course (Cocozza, 2004); (2) analysis of the current state of performance of the subjects to be trained and definition of the level of performance to be achieved (Esposito and Mantese, 2003); (3) creation of a dedicated design team, in which several professional figures are involved (e.g., educational design, curriculum planner, content designer, multimedia designer); and (4) the 
selection of e-learning contents has different aims that can be: to transfer information within a training context; to acquire skills from users; to promote an educational model focused on cooperation and shared learning; and finally to promote the dynamics of organisational and shared learning taking place in practice communities (Ghiringhelli and Quacquarelli, in Nacamulli, 2003).

There are different study approaches in literature, in recent years, on e-learning in universities. On the one hand, Hassanzadeh, Kanaani, and Elahi's (2012) research identify a specific model to measure the success of e-learning systems in universities, able according to Islam (2013) to compare different learning platforms in terms of effectiveness and assistance offered to students in their studies and use in the university teaching process (Oproiu, 2015). Furthermore, there is the reference to the creation of an integrated e-learning system architecture able to share the knowledge of some experts and professionals of the university system (Adeola, Adewale and Alese, 2013). Identifying and assessing the skills required by students is also important to provide effective performance in a university e-learning environment mediated by a learning management system (Parkes, Reading and Stein, 2013) suitable for developing creative thinking for higher education students (Songkram, 2015).

On the other hand, we can mention some studies that focus on students' motivation and preferences towards e-learning systems compared to traditional ones. In this regard, research conducted by Castillo-Merino and Serradell-Lopez (2014) has shown that motivation is the only variable that can allow university students enrolled in e-learning courses to perform better than those obtained by students attending courses on the university campus. Chen et al. (2012), through the theory of expectations, explains the reasons why students prefer e-learning technologies. Among the surveys, in this context, those conducted by Kim, Kim, and Li (2015) emerge, which aim to compare the preferences of university students and graduates between two modes of learning: e-learning or traditional learning. Al-Qahtani and Higgins (2013) also state that the adoption of e-learning systems makes it possible to real e students' learning compared to the classical methods used in the classroom. In addition, Bhuasiri et al. (2012) state that we are improving technology-based knowledge and skills, as well as universities' ability to motivate and support users. According to Almpanis (2015), e-learning can also be considered as a tool to implement advanced technological learning in the university context in the UK or to enable sustainable development in higher education (Azeiteiro et al., 2015).

Other authors such as Kurilovas, Kubilinskiene, and Dagiene (2014) focus their investigations on the phenomenon of personalisation of learning within the virtual learning environment of universities, where learning objects are modified. Further studies such as those carried out by Masud (2016) consider the e-learning system character ed by a closed system because it allows access to teaching materials only to students enrolled at the university. According to the Technological Acceptance Model (TAM) described by Al-Adwan, Al-Adwan, and Smedley (2013), this e-learning system can be based on two fundamental elements: ease of use and perceived utility. Elkaseh, Wong, and Fung (2016) also state that user-friendliness and perceived usefulness with the use of social media are key factors in students' assessment and teachers' behavioural intention to accept and use e-learning in higher education.

Based on a different study approach, Khasawneh (2015) and Babić, Čičin-Šain, and Bubaš (2016) examine potential factors using ICT and e-learning in public universities for academic staff, even in mixed environments where there are teachers who are not e-learning users. Also in this context, we can mention Carril, Sanmamed, and Sellés's (2013) surveys which focused 
on obtaining information on the level of teachers responsible for pedagogical skills in online teaching.

However, according to an empirical survey conducted by Urh (2015), universities do not pay attention to the design of e-learning related to the educational aspect (Islam, Beer and Slack, 2015). A correct training requires, in fact, that the teacher knows how to plan and distribute the course materials in e-learning and how to properly guide the students, in order to transmit knowledge, skills and enable the learning process and training management (Trentin, 2001; Fee, 2009).

\section{Methodology}

The literature review focused on the analysis of two international journals: Internet and Higher Education (IEHE) and Computer $\mathcal{E}$ Education (CEE). The former is a quarterly journal dedicated to contemporary issues and future developments related to online learning, teaching and administration on the Internet in post-secondary contexts. ${ }^{1}$ Computers $\mathcal{E}$ Education, on the other hand, aims to increase knowledge and understanding of the ways in which digital technology can improve education, through the publication of high-quality research that extends theory and practice. ${ }^{2}$

These two journals have been selected on the basis of the international ranking provided on the SCImago Journal \& Country Rank (SJR) website. This portal includes national scientific journals and indicators developed from information contained in the Scopus ${ }^{\circledR}$ database (Elsevier B.V.). This platform allows you to check the number of international special ed journals in the different areas and categories. In particular, the survey was carried out by selecting from the drop-down menu relating to 'Thematic Areas' the one relating to 'Social Sciences' and in the 'Thematic Categories' section the one relating to 'Education' on the abovementioned website.

The choice was made on these two journals, compared to others, not according to their chronological order, but for two reasons. First of all, both the chosen journals contain the word 'education' in their names, thus enhancing the scope of our investigation. Secondly, the two journals I\&HE and C\&E consider the combination of technological and educational aspects.

The articles were found on the basis of the titles present in the database of the respective websites, the two journals I\&HE and C\&E, through the inclusion of some keywords. The following keywords have been typed in the websites of the two journals mentioned above, which have been examined so far: 'e-learning' and 'design of e-learning'. We took the period January 1998 to October 2018 for analysis. The choice fell on this long period of time, to verify the different approaches of e-learning study that have occurred over time in the academic field.

The analysis of the various journals has also been implemented, considering the list of articles found on their respective websites, only those that are called 'Research Articles' because the content of their abstracts is easily accessible. In fact, all the types that we simply called 'Other

\footnotetext{
${ }^{1}$ Further information can be found online at https://www.journals.elsevier.com/the-internet-andhigher-education (last accessed: April 11, 2020).

2 Further information can be found online at https://www.journals.elsevier.com/computers-andeducation/ (last accessed: April 11, 2020).
} 
Sections' have been excluded from the sample, that is: Review, Book Reviews, Discussion, Editorials, Product Reviews, Short Communication, Other. This element, therefore, led to a greater vision in terms of the number of items found, even if they were subsequently discarded.

We created a special database on an Excel spreadsheet that allowed us to select and transpose the different titles of the articles and their abstracts viewed by the websites of the aforementioned journals. It has been verified that, sometimes, the same title of an article, searched with a keyword, was calculated in the total number of those subsequently searched with another keyword, since both terms coexisted in the content of the same article.

The investigation, in its entirety, will take place at two specific times: (1) a first selection based on keywords on the sites of the two journals; (2) a second selection phase to choose the most coherent studies. The first selection concerned the identification of titles containing keywords related to the phenomenon of e-learning in the university context. The following keywords have been typed in the websites of the two journals (I\&HE and C\&E): 'e-learning' and 'design of e-learning'.

The keyword search, while respecting the criterion of completeness, has the defect of being too generic. It was therefore necessary to better verify the content of the titles by analysing in detail the abstracts of the individual articles, in order to identify those most consistent with elearning/e-learning design in universities. Not only that, it was necessary to examine the topic dealt with in the individual abstracts selected, in order to draw up a provisional ranking and to arrange its contents within one of the categories identified in the Fee model (2009), namely: (a) technology; (b) learning content; and (c) e-learning design.

\section{Main results and discussion}

In the journal I\&HE, 185 titles were traced by typing the keyword 'e-learning', of which 38 were excluded from the survey, as they belonged to the Other Sections. In particular, the research articles examined were No. 147, where No. 9 referring to e-learning in universities was found (see Table 4.1).

With the keyword 'design of e-learning', 10 articles emerged, of which 2 related to Other Sections. No. 8 (Research Articles) has been considered, of which No. 1 can be linked to the design of e-learning in universities.

The total number of articles analysed in the journal I\&HE was 155, of which only 9 are attributable to e-learning within universities.

\begin{tabular}{|c|c|c|c|c|}
\hline Keywords & Journal & $\begin{array}{l}\text { Number of } \\
\text { papers found }\end{array}$ & $\begin{array}{l}\text { Number of } \\
\text { papers } \\
\text { considered } \\
\text { appropriate }\end{array}$ & Authors \\
\hline e-learning & I\&HE & 147 & 9 & $\begin{array}{c}\text { O'Droma, Ganchev, and } \\
\text { McDonnell (2003); } \\
\text { Paechter and Maier (2010a); } \\
\text { Teo (2010); Parkes, Stein, and } \\
\text { Reading (2015); Owston, York, }\end{array}$ \\
\hline
\end{tabular}




\section{punt(Oorg}

\begin{tabular}{|c|c|c|c|c|}
\hline Keywords & Journal & $\begin{array}{l}\text { Number of } \\
\text { papers found }\end{array}$ & $\begin{array}{l}\text { Number of } \\
\text { papers } \\
\text { considered } \\
\text { appropriate }\end{array}$ & Authors \\
\hline & & & & $\begin{array}{c}\text { and Murtha (2013); Smith, } \\
\text { Heindel, and Torres-Ayala } \\
\text { (2008); } \\
\text { Nichols and Levy (2009); } \\
\text { Muzio, Heins, and Mundell } \\
\text { (2002); } \\
\text { McGill, Klobas, and Renzi } \\
\text { (2014). }\end{array}$ \\
\hline \multirow[t]{2}{*}{ design of e-learning } & I\&HE & 8 & 1 & $\begin{array}{l}\text { O'Droma, Ganchev, and } \\
\text { McDonnell (2003). }\end{array}$ \\
\hline & I\&HE & 155 & 9 & \\
\hline
\end{tabular}

Table 4.1. Number of papers searched in The Internet and Higher Education (IEHE) journal. Period from 1998 to 2018.

In the C\&E journal, by entering the keyword 'e-learning', a total of 799 titles were registered, of which 16 articles belonging to Other Sections. In particular, 783 articles (Research Articles) were examined, of which 20 related to e-learning in universities (see Table 4.2).

\begin{tabular}{|c|c|c|c|c|}
\hline Keywords & Journal & $\begin{array}{c}\text { Number of } \\
\text { papers found }\end{array}$ & $\begin{array}{c}\text { Number of } \\
\text { papers } \\
\text { considered } \\
\text { appropriate }\end{array}$ & Authors \\
\hline e-learning & $C \& E$ & 783 & 20 & $\begin{array}{l}\text { Alhabeeb and Rowley (2018); } \\
\text { Cidral et al. (2018); } \\
\text { Paechter, Maier, and Macher } \\
\text { (2010b); } \\
\text { Chang, Hajiyev, and Su (2017); } \\
\text { Bhuasiri et al. (2012); Wu and Lin } \\
\text { (2012); Awidi and Cooper (2015); } \\
\text { Biasutti (2011); } \\
\text { Al-Samarraie, Teo, and Abbas } \\
\text { (2013); Ozkan and Koseler (2009); } \\
\text { Fu, Su, and Yu (2009); Duan et al. } \\
\text { (2010); } \\
\text { Darab and Montarez (2011); } \\
\text { Mahdizadeh, Biemans, and } \\
\text { Mulder (2008); } \\
\text { Arenas-Gaitán, Ramírez-Correa, } \\
\text { and Rondán-Cataluña (2011); } \\
\text { Jones et al. (2010); Islam (2013); } \\
\text { González-Gómez et al. (2012); } \\
\text { Cho, Cheng, and Lai (2009); Selim } \\
\text { (2007). }\end{array}$ \\
\hline
\end{tabular}




\begin{tabular}{|c|c|c|c|c|}
\hline Keywords & Journal & $\begin{array}{c}\text { Number of } \\
\text { papers found }\end{array}$ & $\begin{array}{c}\text { Number of } \\
\text { papers } \\
\text { considered } \\
\text { appropriate }\end{array}$ & Authors \\
\hline
\end{tabular}

design of e-learning $\quad$ C\&E $\quad 39 \quad 2$

2 Chang, Hajiyev, and Su (2017);

Cho, Cheng, and Lai (2009).

C\&E $\quad 822 \quad 20$

Table 4.2. Number of papers searched in Computers $\mathcal{E}$ Education (CEE) journal. Period from 1998 to 2018.

With the keyword 'design of e-learning', 39 articles emerged, of which only No. 2 can be traced back to the design of e-learning in universities. The total number of articles analysed in C\&E journal was 822 , of which only 20 articles are related to e-learning in universities.

Table 4.1 and Table 4.2 show, for I\&HE and C\&E journals, clearly: the total number of articles found on the basis of the keyword entered, those selected on the basis of argumentative consistency, as well as their bibliographical reference. It should be clarified that in the overall calculation of the articles considered appropriate for the research, reported in Table 4.1, we have not considered the numerical value based on the articles detected by keywords, but on the identity of the authors. Therefore, the number of articles detected was 9 and not 10. In particular, the bibliographic reference concerning O'Droma, Ganchev, and McDonnell (2003), even if found and inserted within the scheme with different keywords (reporting articles No. 2 ), is, in reality, unique, as better highlighted in bold. The same problem arises in Table 4.2, where the reference to Chang, Hajiyev, and Su (2017) and Cho, Cheng, and Lai (2009) is reported with both the keyword 'e-learning' and the keyword 'design of e-learning'. The total number of elements considered appropriate, therefore, in their content is 20 and not according to algebraic sum No. 22.

Resuming the study on the three components of the e-learning systems (technology; learning content; e-learning design) outlined by Fee (2009) and on the basis of the analysis of the 29 abstracts surveyed and examined, in particular, we can draw up a classification, on a provisional basis, to highlight the content of the issues addressed.

\subsection{Technology}

As for the technology component, all those studies that focus on the Model of Acceptance of Technology (TAM), such as the one outlined by Arenas-Gaitán, Ramírez- Correa, and RondánCataluña (2011), in which cultural differences are examined, have emerged (based on Hofstede's studies) and the technological acceptance of students from two universities: one Spanish and the other Chilean. However, we can refer to Teo's (2010) research to measure the degree of acceptance by e-learning users. Islam (2013) also focuses on perceived utility and perceived ease of use, while Awidi and Cooper (2015) analyse management approaches to facilitate the implementation of e-learning in one of Ghana's leading universities. On the contrary, Cidral et al. (2018) in their survey aim to find the determinants of user perceived 
satisfaction, use and individual impact of e-learning through the introduction of a specific theoretical model.

Other research, such as that of, for example, Ozkan and Koseler (2009), exposes a conceptual model of evaluation of the Learning Management System (LMS) through student satisfaction, or that of Parkes, Stein, and Reading (2015) exploring the perceptions of students and staff at the level of student preparation for a university e-learning environment mediated by a Learning Management System (LMS). Mahdizadeh, Biemans, and Mulder (2008) focus on factors that may explain the use of e-learning environments by teachers in universities, while Jones et al. (2010) have shown that generation is not homogeneous in the use and appreciation of new technologies and that there are significant variations among students who are in the age group of the network generation. Finally, Smith, Heindel, and Torres-Ayala (2008) consider the use of two widely available data sources the use logs of Content Management System (CMS) tools and course evaluations to analyse the differences between online courses at a large university.

\subsection{Learning content}

With regard to the learning content component, we have to consider several investigations. For example, Alhabeeb and Rowley (2018) to promote the knowledge of the factors leading to the success of e-learning in universities have demonstrated through a comparative study of the perspectives of academic staff and students regarding the learning content of the system as a whole or by comparing two groups of stakeholders: ICT experts and university faculties (Bhuasiri et al., 2012). Fu, Su, and Yu (2009) in their research also demonstrate how the level of e-learning content can be measured on a scale that refers to the fun offered by online courses based on games held at a given university. Different is the survey conducted by Biasutti (2011) which presents a picture of students' experience of the contents of a collaborative e-learning module in an asynchronous e-learning environment of a university, while the studies of Paechter, Maier, and Macher (2010b) are related to perceived learning outcomes and satisfaction with e-learning courses. On the contrary, Al-Samarraie, Teo, and Abbas (2013) propose an e-learning model to assess the effects of online structured representation of content attributable to the understanding of university students, or based on comparative studies and expert opinions (Darab and Montazer, 2011) or to provide evidence on the question whether there are gender differences between male and female students on topics studied by e-learning (González-Gómez et al., 2012). According to Duan et al. (2010), it is possible to understand, from the point of view of the adoption of innovation, the intention of Chinese university students of e-learning courses by referring to the type of teaching material or curriculum provided also on the basis of the perception by university students of the critical success factors of e-learning (Selim, 2007).

Other research, such as that of $\mathrm{Wu}$ and Lin (2012), aims to develop an analytical model to improve the quality of e-learning service using an approach with the provision of teaching materials or mixed-mode teaching programmes; either based on the preferences of students at some Austrian universities over face-to-face learning (Paechter and Maier, 2010) or based on certain factors based on students' motivation, satisfaction and previous academic performance measures (Nichols and Levy, 2009). Further study approaches, such as the one conducted by McGill, Klobas, and Renzi (2014), examine the conditions associated with the continuation of 
initiatives in universities through e-learning content based on a literature review. Very different is the viewpoint observed by Muzio, Heins, and Mundell (2002) who analyse the creation of e-learning courses as a content management tool by combining reusable e-learning objects (ELO) in a research centre of a Canadian university. Finally, according to Owston, York, and Murtha (2013), there is a relationship between the perception of university students on the contents of courses carried out through blended learning and the results obtained. An extraordinarily strong relationship has been found between perceptions and evaluations. Compared to poorly performing students, the best performing students were more satisfied with the content of the combined course, would have followed another one and would have preferred the combined format to other types.

\subsection{E-learning design}

As for the third component outlined by Fee (2009), that is, e-learning design, we found only three studies. In this sense, the research by Chang, Hajiyev, and Su (2017) emerges which, through an empirical study, focuses on the use of the general model to determine the factors that influence the behavioural intention (BI) of university students in terms of design of elearning systems in universities. Cho, Cheng, and Lai (2009) also present a theoretical model for assessing the impact of e-learning design through a survey of Hong Kong university students.

In contrast, O'Droma, Ganchev, and McDonnell (2003) focus on a comparative analysis of the design of e-learning systems to assess how their functionality meets the requirements of a virtual university e-learning information system (VUIS).

The exploration as a whole has shown that throughout the period studied, but especially since 2002 and afterwards there are reflections of the scientific community on e-learning in the university context.

In addition, the following considerations can be deduced from the examination of these 29 abstracts in particular. There is a focus by scholars on e-learning in universities, through the survey conducted with the literature review in the two journals I\&HE and C\&E, and based on Fee's (2009) model on the learning content, but also on the technological aspect. Finally, it is clear that there are some studies focusing on e-learning design. From the analysis of the abstracts of these studies found on e-learning design it would seem that there are no references to e-learning design as a learning process outlined in the Trentin (2001) model and characterised by the four phases outlined in the initial paragraphs.

\section{Conclusion}

The keyword search, while respecting the criterion of completeness, has the defect of being too generic. The analysis of the articles found in this work was carried out considering the content of the abstracts, in a very brief way, through a descriptive analysis. The coherence of the articles found with respect to e-learning in universities, at this early stage, was implemented by verifying the explicit presence of the term 'university', in the title of the article and within the individual abstract identified. 
In addition, a classification has been elaborated and drafted, in the experimental phase, which groups the relative contributions found, based on the content of their abstract, within the three elements identified in Fee's (2009) model, namely technology, learning content, and e-learning design, to allow a better understanding of the issues addressed, in detail, by the authors.

Overall, the research has some major limitations. Firstly, in the current work we have not examined the content, in its entirety, of all the articles on the website of the two journals to confirm or not the picture just outlined and to arrive at more comprehensive and incisive discussions on the subject. Secondly, the journals selected and used for the survey were small and did not allow us to know the phenomenon in its complexity.

The future objectives of our research will be:

a) finding of all the articles we have traced through the websites of the journals (I\&HE and $\mathrm{C} \& \mathrm{E})$ only the abstracts in order to carefully check and analyse their content.

b) studying four other journals already specially selected on the basis of the criteria previously highlighted in this article, within the international ranking on the website of SCImago Journal \& Country Rank (SJR), which are respectively: (1) Research in Higher Education (RHE); (2) Studies in Higher Education (SHE); (3) Academy of Management Learning and Education (AMLE); and (4) Journal of Management Education (JME), and the most relevant bibliographical references in related articles.

\section{Keywords}

e-learning; universities; design of e-learning; e-learning design; higher education

\section{Reference list}

Adeola, O. S., Adewale, O.S., and Alese, B.K. (2013), “Integrated e-learning system (IES) for Nigerian universities: an architectural overview", American Journal of Database Theory and Application, 2 (1): 1-8.

Al Qahtani, A.A., and Higgins, S.E. (2013), “Effects of traditional, blended and e-learning on student achievement in higher education", Computer Aided Learning Journal, 29 (3): 220234.

Al-Adwan, A., and Smedley, J. (2013), “Explore the acceptance of e-learning by students using the technology acceptance model in Jordanian universities", International Journal of Education and Development using Information and Communication Technology, 9 (2): 4.

Alhabeeb, A., and Rowley, J. (2018), "Critical success factors of e-learning: Comparing the perspectives of academic staff and students", Computer and Instruction, 127: 1-12.

Alkhalaf, S., Drew, S., and Alhussain, T. (2012), "Evaluation of the impact of e-learning systems on learners: a survey study in KSA", Procedural, social and behavioral sciences, 47: 98-104.

Almpanis, T. (2015), "Staff Development and Institutional Support for Technology Enhanced Learning in UK Universities", Giornale elettronico di e-Learning, 13 (5): 366-375.

Al-Samarraie, H., Teo, T., and Abbas, M. (2013), "Can structured representation improve students' thinking skills for a better understanding of e-learning content?", Computer $\mathcal{E}$ Education, 69: 463-473. 
Al-Yahya, M., George, R., and Alfaries, A. (2015), “Ontologie nell'e-learning: revisione della letteratura", International Journal of Software Engineering and Its Applications, 9 (2): 67-84.

Arenas-Gaitán, J., Ramírez-Correa, P.E., and Rondán-Cataluña, F.J. (2011), “Intercultural analysis of the use and perceptions of web-based learning systems", Computer and Instruction, 57 (2): 1762-1774.

Awidi, I.T., Cooper, M. (2015), “Using gaps in management procedures to improve the implementation of e-learning in Africa", Computer and education, 90: 64-79.

Azeiteiro, U.M., Bacelar-Nicolau, P., Caetano, F.J., and Caeiro, S. (2015), “Education for sustainable development through e-learning in higher education: experiences from Portugal", Cleanest Production Journal, 106: 308-319.

Babić, S., Čičin-Šain, M., and Bubaš, G. (2016, January), "A study on factors influencing the intention of higher education teachers to use e-learning in hybrid environments", Computer in Education (EC).

Bhuasiri, W., Xaymoungkhoun, O., Zo, H., Rho, J., and Ciganek, A.P. (2012), “Critical success factors for e-learning in developing countries: A comparative analysis between ICT experts and teachers", Computer \& Education, 58 (2): 843-855.

Biasutti, M. (2011), “The student's experience of a collaborative university e-learning module”, Computer and Instruction, 57 (3): 1865-1875.

Brown, A.R., and Voltz, B.D. (2005) "Elements of effective e-learning design", The International Review of Research in Open and Distributed Learning, 6 (1).

Carril, P.C.M., Sanmamed, M.G., and Sellés, N.H. (2013), "Roles and pedagogical skills of university lecturers practising in the e-learning environment", The International Review of Research in Open and Distributed Learning, 14 (3): 462-487.

Carroll, N. (2013), “E-learning - the McDonaldization of Education”, European Journal of Higher Education, 3 (4): 342-356.

Castillo-Merino, D., and Serradell-López, E. (2014), “An analysis of the determinants of students' performance in e-learning", Computer in Human Behavior, 30: 476-484.

Chang, C.T., Hajiyev, J., Su, C.R. (2017), “Examining the students' behavioural intention to use e-learning in Azerbaijan? The general model of acceptance of extended technology for elearning approach", Computer and Education, 111: 128- 143.

Chen, M.Y., Chang, F.M.T., Chen, C.C., Huang, M.J., Chen, J.W. (2012), “Why do individuals use electronic wallets? Technology and educational society, 15 (4): 114- 125.

Cho, V., Cheng, T.E., Lai, W.J. (2009), "The role of user interface design perceived in the intention to continue to use self-learning tools", Computer \& Education, 53 (2): 216-227.

Cidral, W.A., Oliveira, T., Di Felice, M., and Aparicio, M. (2018), "The determinants of elearning success: Brazilian empirical study", Computer and Education, 122: 273-290.

Clark, R.C., and Mayer, R.E. (2011), E-learning and educational science: Proven guidelines for consumers and multimedia learning designers, John Wiley \& Sons.

CNPA (2007), ASFOR Glossary "The words of e-Learning", Cnipa (ed.), Vademecum for the implementation of e-learning training projects in public administrations. The Edition. Cnpa Notebooks, 32, 347-399. 
Cocozza, A. (2006), Human Resources Department. Policies and tools for the organization and management of work relations, Milan: FrancoAngeli.

Conole, G. (2013), Design for learning in an open world, London: Springer Science \& Business Media, London.

Darab, B., and Montazer, G.A. (2011), "An eclectic model for assessing e-learning readiness in Iranian universities", Computer $\mathcal{E}$ Education, 56 (3): 900-910.

Duan, Y., He, Q., Feng, W., Li, D., and Fu, Z. (2010), “A study on the intention to adopt elearning from the point of view of adopting innovation: A case in point in China", Computer \& Education, 55 (1): 237-246.

Elkaseh, A.M., Wong, K.W., and Fung, C.C. (2016), "Perceived the ease of use and perceived usefulness of social media for e-learning in Libyan higher education: a modeling analysis of the structural equation", International Journal of Information and Education Technology, 6 (3): 192-199.

Esposito, G., and Mantese G. (2003), E-learning: an operational guide. How to realize and evaluate a project, Milan: FrancoAngeli.

Fu, F.L., Su, R.C., and Yu, S.C. (2009), “EGameFlow: a scale for measuring student enjoyment in e-learning games", Computer and Instruction, 52 (1): 101-112.

Ghiringhelli C., and Quacquarelli, B. (2003), "Designing learning on and off the net", in R.C.D. Nacamulli (ed.), The Formation, Cement and Net, pp. 139-178, Milan: Etas.

González-Gómez, F., Guardiola, J., Rodríguez, Ó.M., and Alonso, M.Á.M. (2012), “Gender differences in e-learning satisfaction", Computer and Instruction, 58 (1): 283-290.

Gros, B., and García-Peñalvo, F.J. (2016), “Future trends in design strategies and technological costs of e-learning", in M. Spector, B.B. Lockee and M.D. Childress (eds), Learning, design and technology. An International Compendium of Theory, Research, Practice, and Policy, pp. 123, Cham: Springer.

Hassanzadeh, A., Kanaani, F., and Elahi, S. (2012), "A model for measuring the success of elearning systems in universities", Expert Systems with Applications, 39 (12): 10959-10966.

Horton, W. (2011), E-learning by Design, John Wiley \& Sons.

Huang, E.Y., Lin, S.W., Huang, T.K. (2012), "What kind of learning style leads to online participation in the e-learning environment in blended mode? A study on the instructions for use of the software", Computer \& Education, 58(1): 338- 349.

Islam, A.N. (2013), "Investigate the results of the use of the e-learning system in the university context", Computer \& Education, 69: 387-399.

Islam, N., Beer, M., Slack, F. (2015), “The challenges of e-learning faced by academics in higher education", Journal of Education and Training Studies, 3 (5): 102-112.

Jones, C., Ramanau, R., Cross, S., Healing, G. (2010), “Net generation" or “Digital Natives": Is there a distinct new generation entering the university? Computer $\mathcal{E}$ Instruction, 54(3): $722-732$

Kim, Y.J.J., Kim, J.H., Li, M.H. (2015), “Web-Enhanced Teaching and Learning Vehicle Preference in Landscape Architecture Construction Studio Courses", Giornale dell'elearning e dell'istruzione superiore, 2015: 1-8. 
Klimov, B.F. (2012), "ICT versus traditional approaches to teaching", Procedural, social and behavioral sciences, 47: 196-200.

Kurilovas, E., Kubilinskiene, S., Dagiene, V. (2014), “Web 3.0-Based customizations of learning objects in virtual learning environments", Computer in Human Behavior, 30: 654-662.

Lloyd, M.M. (2005), "Towards a definition of ICT integration in the classroom", Acts AARE '05 Education Research.

Loh, C., Wong, D.H., Quazi, A., Kingshott, R.P. (2016), Review students' perception of elearning: an Australian perspective. International Journal of Educational Management, 30 (1): 129-139.

Mahdizadeh, H., Biemans, H., Mulder, M. (2008), “Determining factors in the use of e-learning environments by academics", Computer and instruction, 51(1): 142-154.

Masud, M. (2016), "Collaborative e-learning systems using semantic data interoperability", Computer to Human Behavior, 61: 127-135.

McGill, T.J., Klobas, J.E., and Renzi, S. (2014), "Critical success factors for the continuation of e-learning initiatives", Internet and higher education, 22: 24-36.

Muzio, J.A., Heins, T., and Mundell, R. (2002), Experiences with reusable e-learning objects: From theory to practice", Internet and higher education, 5(1): 21-34.

Nichols, A.J., Levy, Y. (2009), “Empirical evaluation of the persistence of university studentsathletes in e-learning courses: A case study of an institution of the US National Association of Intercollegiate Athletics (NAIA)", Internet and higher education, 12(1): 1425.

O'Droma, M.S., Ganchev, I., McDonnell, F. (2003), Architectural and functional design and evaluation of e-learning VUIS based on the proposed IEEE LTSA reference model. Internet and higher education, 6(3), 263-276.

Oproiu, G.C. (2015), "A study on the use of the e-learning platform (Moodle) in the university teaching process", Procedural, social and behavioral sciences, 180: 426- 432.

Owston, R., York, D., Murtha, S. (2013), "Student perceptions and achievements in a strategic university blended learning initiative", Internet and higher education, 18: 38-46.

Ozkan, S., Koseler, R. (2009), "Multidimensional student assessment of e-learning systems in the context of higher education": An empirical survey", Computer and instruction, 53(4): 1285-1296.

Paechter, M., Maier, B. (2010a), “Online or face-to-face”? Students' experiences and preferences in e-learning", Internet and higher education, 13(4): 292-297.

Paechter, M., Maier, B., and Macher, D. (2010b), “Students' expectations and e-learning experiences: Their relationship to learning outcomes and course satisfaction", Computer and education, 54(1): 222-229.

Parkes, M., Reading, C. and Stein, S. (2013), "The skills needed for effective performance in a university e-learning environment", Australasian Journal of Educational Technology, 29, (6).

Parkes, M., Stein, S. and Reading C. (2015), "Preparing students for university e-learning environments", Internet and higher education, 25: 1-10. 
Rienties, B., Toetenel, L. and Bryan A. (2015), “Scaling learning design: impact of learning design activities on the behaviour and performance of LMS", Proceedings of the Fifth International Conference on Learning to Analyse and Knowledge, LAK '15, ACM, 315-319.

Selim, H.M. (2007), Critical success factors for e-learning acceptance: Confirmation factor models. computer $\mathcal{E}$ education, 49(2), 396-413.

Smith, G.G., Heindel, A.J., and Torres-Ayala, A.T. (2008), "E-learning commodity or community": Disciplinary differences between online courses. Internet and higher education, 11(3-4): 152-159.

Songkram, N. (2015), "e-learning system in virtual learning environment to develop creative thinking for higher education students", Procedural, social and behavioral sciences, 174: 674679 .

Soup, C.M. (2012), "Defining ICT in a world without borders: The development of a hierarchy of work", International Journal of Information Technology Management, 4(3): 13.

Tax, K. (2009), Providing E-Learning: A comprehensive strategy for design application and evaluation, Kogan Page Publishers, London.

Teo, T. (2010), "Development and validation of the e-learning acceptance measure (ElAM)", Internet and Higher Education, 13 (3): 148-152.

Trentin, G. (2001), From distance learning to online learning, Milan: FrancoAngeli.

Urh, M., Vukovic, G. Jereb, E. (2015), “The model for the introduction of gamification in elearning in higher education", Procedural, Social and Behavioral Sciences, 197: 388-397.

Wu, H.Y., Lin, H.Y. (2012), "A hybrid approach to develop an analytical model to improve the quality of e-learning service", Computer $\mathcal{E}$ Education, 58 (4): 1318-1338. 